表 4 低炭秦社会の実現のための方向性

\begin{tabular}{|c|c|c|}
\hline & \multicolumn{2}{|c|}{ 化石燃料の高度利用 $\rightarrow$ （a） $\rightarrow$ 再生可能エネルギー等利用 } \\
\hline 「点」 & $\begin{array}{l}\text { (1) 化石燃料の高度利用 } \\
\text { •CGS 本体や廃熱利用機器の高効率化, 分散型エネル } \\
\text { ギーシステムの高効率化, 建物全体システムの省エネ } \\
\text { 化等により推進 }\end{array}$ & $\begin{array}{l}\text { (2) 再生可能エネルギー等の活用 } \\
\text { •再生可能エネルギー等の安定的かつ効率的利用のため } \\
\text { のシステム化 (CGS とのシステム化: 太陽熱・光, バ } \\
\text { イオエネルギー等) }\end{array}$ \\
\hline 面・ネットワーク & $\begin{array}{l}\text { (3) 面・ネットワークに関するコミュニティーレベルの対 } \\
\text { 策 } \\
\text { ·熱・電気の面的利用による低炭素化の推進 } \\
\text { ·建物間から街区間さらに地域・都市計画まで含めた対 } \\
\text { 策へ拡大 }\end{array}$ & $\begin{array}{l}\text { (4) スマートエネルギーネットワーク化（EU, 豪州でも } \\
\text { 検討) } \\
\text { ·熱・電気のネットワーク化による全体最適化 } \\
\text { · ICT 活用による最適なエネルギーマネージメントの実 } \\
\text { 現 }\end{array}$ \\
\hline
\end{tabular}

されるため，欧州でも重要な対策に位置付けられている。

\section{(3) エネルギーの面的・ネットワーク的利用の推進}

エネルギーシステムの導入・利用に当たっては, 機器・シ ステムや建物単位といった「点」での対策では, 部分負荷運転 による効率低下や大規模高効率システムの導入等が困難と いった課題がある。これらの課題を解決するためには，工ネ ルギーの「面的・ネットワーク的利用」を推進することが重要 である。面的利用のメリットは，需要集約による部分負荷運 転の回避, コージェネレーションシステム等の高効率機器の 導入, 再生可能エネルギー等の活用等であり，これにより個 別対策では実現困難な大幅な $\mathrm{CO}_{2}$ 削減が可能となる。

また，面的利用は，エネルギーシステムの多重化による災 害等緊急時等の都市の業務・生活機能の継続機能といったセ キュリティの向上にも貢献することから, 都市の低炭素化·高 機能化のためにはきわめて重要な対策である。

\section{(4)「スマートエネルギーネットワーク」への進化}

現在，太陽光等の再生可能エネルギーのさらなる導入を目 指し，情報通信技術も活用し，電力系統を最適に管理する「ス マート・グリッド」が議論されているが，欧州でも，電力のみ ならず，ガスや蒸気，冷水，温水等を包含したより進化した 概念である「スマートエネルギーネットワーク」の検討が進 められている。

エネルギーの高度利用，再生可能エネルギー等の活用，面 的利用の推進を図るためには，グリッドのスマート化だけで はなく，清掃工場廃熱をはじめ, CGS 廃熱，太陽熱やバイオ マス等の熱も有効利用する熱のネットワーク化，さらには究 極の低炭素エネルギーである水素利用も可能とする水素ネッ トワークも視野に，柔軟性・拡張性を持ったエネルギーのス マート化，ネットワーク化を順次推進することが必要である。 これにより，真のエネルギーのベストミックス化と，技術革 新に伴い進化するシステム構築が可能となる。

国レベルでも，経済産業省が，国土交通省・環境省等と連携 し，再生可能エネルギー熱や未利用熱を含む熱エネルギーを 融通する，いわゆる「エネルギーの面的利用の推進」に向け た制度的課題や支援措置について検討する「まちづくりと一 体となった熱エネルギーの有効利用に関する研究会」を 2011 年 5 月よりスタートさせた。
さらに，エネルギーの有効利用という観点からは，電力だ けでなく, 熱エネルギーや交通システムも含め,「スマートコ ミュニティ」ともいうべき，人々のライフスタイル全体を視 野に入れた社会システムの検討も始まっている。

\section{文 献：Reference}

1）（財)天然ガス導入促進センター エネルギー高度利用促進本部，コー ジェネレーションシステム導入実績調查より作成２）(財)天然ガス導入 促進センター エネルギー高度利用促進本部，コージェネレーションシステ ム白書 2010 3）日本コージェネレーションセンター,コージェネレー ションシステム原動機別データ集 2007 年より作成

\section{2 ヒートポンプ}

1. ヒートポンプとは

ヒートポンプとは「熱は温度の高いところから低い方へ流 れる」と言う基本原理を利用したもので，熱移動媒体 (冷媒) を圧縮して圧力（温度）を上げたり，膨張により圧力（温度） を下げたりを繰り返す中で，見掛け上温度の低いところから 高いところへ熱の移動（文字通り熱の汲み上げ）を行うもの である。従来から冷蔵庫やエアコンなど身近な製品に応用さ れ目新しい技術ではないが，近年省エネルギー・地球温暖化 防止対策としての $\mathrm{CO}_{2}$ 排出削減の要求とともにその汲み上げ (エネルギー) 効率向上や太陽から与えられた無尽蔵とも言え る大気が持つ熱を利用することからさらに注目が集まり，本 技術を用いた機器の利用範囲は広がっている(図 1)。

そのエネルギー効率の良さについて暖房を例にしてヒート ポンプの仕組みを紹介する。『1」の電力を使って冷媒を圧縮 したサイクルで，大気から『4』の熱量を汲み上げれば，室 内側で『 $1+4 \rrbracket=『 5 』 の$ 熱量を取り出すことができる。つ まり，使用したエネルギーの 5 倍の熱量を得ることが可能と なる(これをCOP [成績係数] が 5 であるという指標で表す)。 最近のエアコンでは飛躍的にこの性能が向上しており, COP でみると 6 以上の商品も次々と発売されている。

そしてこのヒートポンプ技術は, 日本は世界でも最高レベ ルの技術を有するとともに，電力消費量抑制に奇与可能なも のである。 

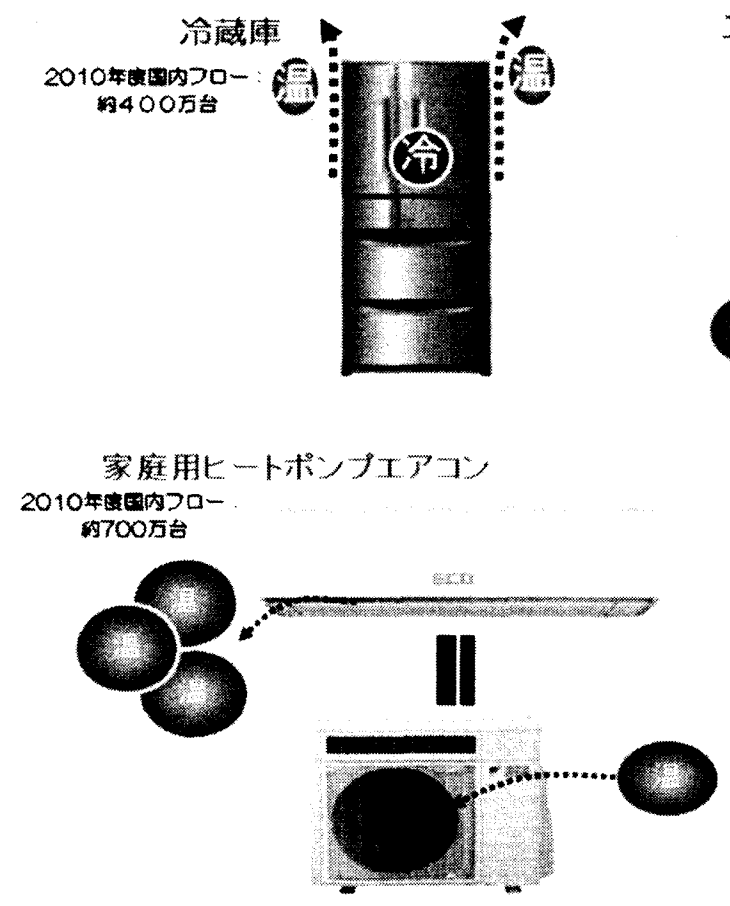

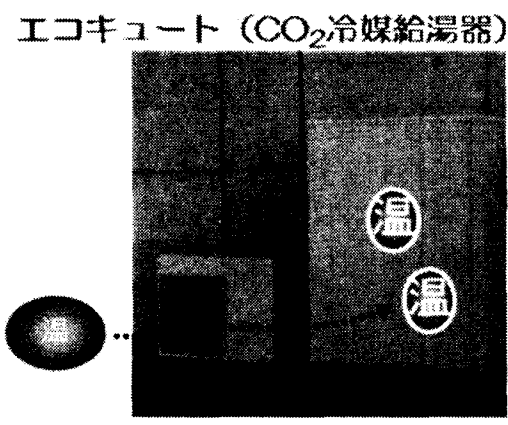

ヒートボンブ式洗濯乾燥機

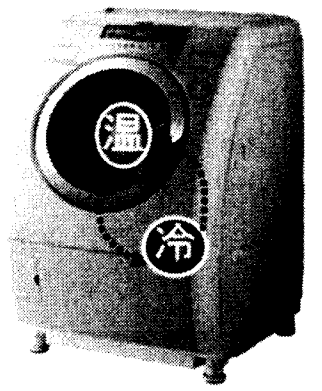

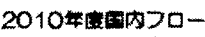
\$55

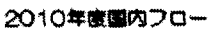
胡15万台

\section{2. 近年の技術動向}

標準的な空調エアコン以外で特に近年の製品化が進み技術 動向の変化の大きい製品について以下に紹介する。

(1)ターボ冷凍機の高性能化（図 2 )

ターボ冷凍機はビル空調などの大型冷房や, 工場の空調, プ ラント等におけるプロセス冷却など，広範な用途に採用され ている冷熱源機である。ターボ冷凍機は, 高速回転する羽根 車が冷媒を強い遠心力で効率的に圧縮する仕組みで, 定格運 転でのCOPが 7 に達するものが販売されている。また，最新 のターボ冷凍機では，インバー夕技術を用いて冷媒を圧縮す るコンプレッサーの最適回転数制御を行うことなどにより， 部分負荷時に更に高効率となる機器も出てきた。

（2）高性能ヒートポンプ給湯機の登場（図 3 ）

ヒートポンプ技術が進むとともに，今まで化石燃料の燃焼 に頼っていた給湯分野に扔いても，ヒートポンプ化が進み， 年々その性能が向上し, 今では COP5 以上の高性能の機器が 開発されている。家庭用のヒートポンプ給湯機は主に「エコ

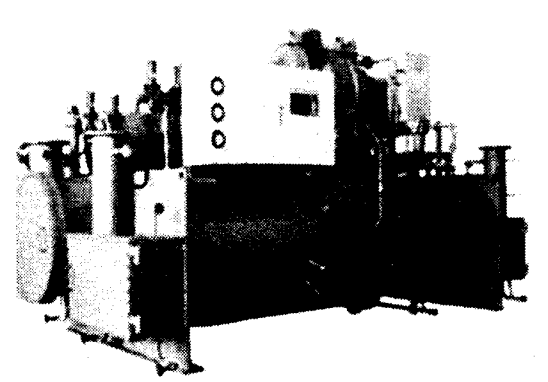

\section{0年度国内2} 口-: 約400台

図 2 高性能ターボ冷凍機
キュート」という名称で親しまれ，2009 年には全国の家庭で 導入台数が 200 万台を越え，2010 年には 280 万台まで広がっ た。また，業務用でも小規模の飲食店で用いられる比較的小 容量のものから，スポーツ施設などで用いられる中大型容量 のものまで，ラインナップされている。エネルギー消費量が 近年伸びているのは，業務用分野や家庭用分野であり，その 中でも給湯は業務用分野のエネルギーの 2 割, 家庭用分野で は 3 割近くを占めている。この給湯分野に, ヒートポンプ給 湯機を採用することで大幅な $\mathrm{CO}_{2}$ 削隇が期待される。

\section{(3)寒冷地向けヒートポンプ}

最新のインバータとインジェクション冷媒サイクル，2段 圧縮方式の採用, 低外気温性能の優れた圧縮機の搭載などや 除霜運転時間の短縮により, 低外気温で時での暖房能力や短

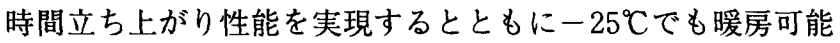
としたことで, 寒冷地における建物の断熱性, 気密性の向上 と相まってヒートポンプエアコンで十分に暖房対応が可能と なった。この結果, 従来燃焼系機器が暖房の主流であった寒 冷地においてもヒートポンプ空調が広がっている。

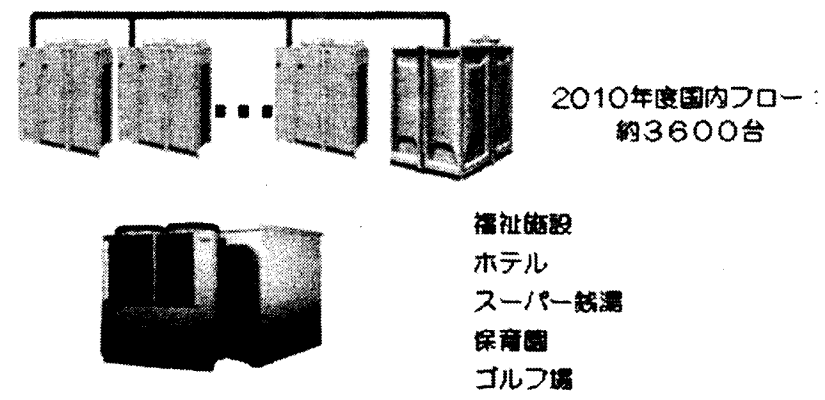

図 3 業務用ヒートポンプ給湯機 
2010 年度国内วロー \$ 7000 台

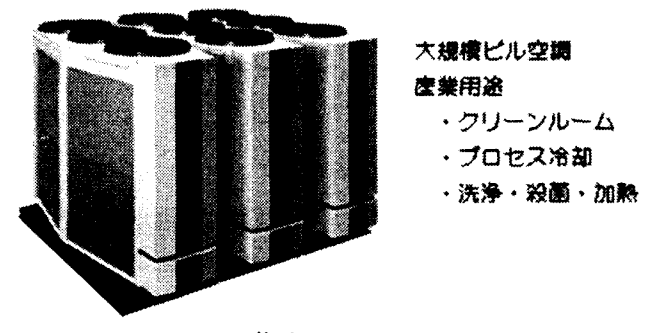

図4モジュール化されたチラー

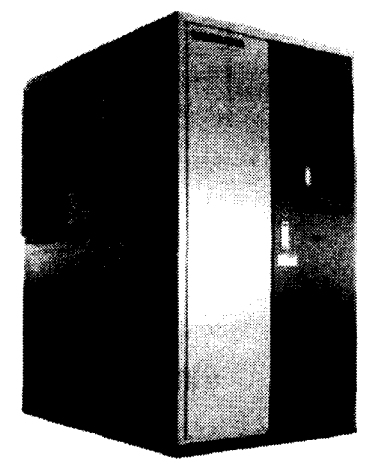

図 5 産業用途ヒートポンプ（出カ $120^{\circ} \mathrm{C}$ )

(4)ヒートポンプチラー（図 4 )

一般の空調設備や工場での生産設備用熱源機としてヒート ポンプチラーが使用されており，冷熱を取り出す冷房専用夕 イプや冷・温熱両方を取り出す様々なタイプが販売されてい る。図 4 に示すように，一部の製品では小さくモジュール化 したものを複数台連結するとともにインバータ駆動を可能に することによって幅広い容量に対応するものも発売され，今 まで設置や搬入で制限のあった施設にも容易に設置可能とし ている。

\section{（5）産業用途ヒートポンプ（図 5)}

工場の生産工程では, ヒートポンプで対応可能な $100^{\circ} \mathrm{C}$ 未渵 の温熱需要が多く存在している。またそれら業種において, 温 熱需要と冷熱需要の両方が存在するため, 温熱・冷熱生成時 の排熱を相互に利用した熱回収ヒートポンプ採用によりさら なるエネルギー効率の向上が図られる。

そして, 大容量化や出力温度の $120^{\circ} \mathrm{C}$ ま゙の高温化技術も 進み，用途は殺菌洗浄や乾燥工程などにも広がっている。

\section{3 蓄熱システム}

\section{1. 蓄熱システムの仕組みとメリット}

蓄熱システムは電力に余裕がありかつ安価な夜間に熱源機 器を効率の良い状態で運転することで熱（冷熱）を蓄え，昼 間の空調負荷に対してその蓄えた熱量を使用することで熱源 機器の小容量化を図り, 省エネルギー性と経済性の向上が可 能なシステムで，環境にやさしいヒートポンプの良さをより
引き出す仕組みとして活用されている。

わが国では，蓄熱空調システムの累計件数は1997年〜2006 年の 10 年間で約 6 倍にも増加し, その後ほぼ1500件/年の増 加傾向で 2009 年には累計約 3 万件となっている。また，電力 負荷平準化に対する効果は大きく，2009 年には 184 万 $\mathrm{kW}$ す なわち発電所 2 基に相当する電力ピークが抑制されており， 今後のさらなる電力消費量の削減手段として高く評価されて いる。

特に, 水蓄熱式空調システムは, 夏季に氷として冷熱を蓄 えることから「エコ・アイス」の愛称で親しまれ普及してきた。

\section{2. 蓄熱システムの種類}

熱を蓄える方法としては，蓄熱媒体の顕熱（液体や固体の 相変化を伴わない温度変化）を利用するものと潜熱（液体・固 体間の融解／凝固の相変化）を利用するものがあり，前者には 「水蓄熱」,「躯体蓄熱」, 後者には「水蓄熱」,「(水以外の) 潜 熱蓄熱」がある。

「水蓄熱」は, 大規模ビルの地下部の二重スラブ内に水を蓄 え，蓄熱する方法が一般的であり最も実績が多く，地域冷暖 房施設のように大きなものでは $10,000 \mathrm{~m}^{3}$ 以上の水槽を設ける ものがある。

「躯体蓄熱」は，建物の躯体へ蓄熱するものであるが，[水 蓄熱]や「潜熱蓄熱」程蓄熱容量を確保できないため補助的 に用いられる。

「水蓄熱」は, $0{ }^{\circ} \mathrm{C}$ の水が $0{ }^{\circ} \mathrm{C}$ 水になるときに $335 \mathrm{~J} / \mathrm{g}$ の 熱を蓄えることを利用し，小さな容積で効率よく冷熱を蓄え る。製水率 $50 \%$ で設置スペースは「水蓄熱」に対し $1 / 7$ とな り,この長所を生かして店舗用などのほほ $7.5 \mathrm{~kW}$ 能力の氷蓄 熱システム（エコアイス mini）にはじまり，ビル空調・大規 模空調にまで使用されている。

「潜熱蓄熱」には上記「氷蓄熱」も含まれるが，水よりも必 要とされる温度に近い温度で凝縮, 融解する媒体を使用する ことで熱源機の効率を高めることができる。媒体には水と有 機媒体を混合したクラスレートやパラフィン系のものがある。

また大地が持つ地中温度に加え, 土壤の断熱性と蓄熱性を 利用する「土中蓄熱」も行われている。

\section{3. 蓄熱式空調システムの方式}

2 項の蓄熱システムを使用した空調システムでは，規模や 設置スペースに合わせてそれぞれの特徴などをいかし，最適 なシステムを選択できる。表 1 に主な蓄熱式空調システムの 種類を示す。

\section{4. 蓄熱システムの動向}

5.2 ヒートポンプの項で述べたように, ヒートポンプ機器の 高性能化が進んでおり，蓄熱システムについても，ここ数年， 東京都心に竣工した大規模開発や大型ビルにおいて，高効率 ターボ冷凍機と大規模な温度成層型水蓄熱槽とを組合せて, システム総合効率が1.5を超え，既存の地域熱供給の平均值の 2 倍以上の効率を達成したという実績が報告され，蓄熱式空 